\title{
Laboratory Studies on the Effects of Different Salt Concentration on Seed Germination
}

\section{Veeral KMD*, Sangameshwari P and Kalaimathi P}

Department of Agronomy, Faculty of Agriculture, Annamalai University, India

*Corresponding author: Kumari Manimuthu Veeral D, Department of Agronomy, Faculty of Agriculture, Annamalai University, India, Email: dkmveeral@gmail.com

\section{Research Article}

Volume 3 Issue 2

Received Date: April 25, 2018

Published Date: May 11, 2018

\section{Abstract}

Salinity is the most severe concern to crop production worldwide causing huge losses to cultivated crops. A laboratory study was carried out to test the effects of salt on seed germination, root and shoot length of rice, black gram and cotton. It was observed that salt concentrations had negative effect on seed germination, root and shoot ratio. Increasing in salt concentration generally caused a progressive retardation in seed germination. As the concentration increased or at higher level, the germination percentage and other parameters were also drastically reduced. Under higher concentrations these plants were died before they were able to grow, bear root and shoot in all three crops.

Keywords: Salt Concentration; Seed Germination

\section{Introduction}

The response of crops to salinity is of great practical significance in Agriculture because the problem becomes more severe year after year. The salinity stress is a major environmental constraint and the first exposure of the crop to the salinity stress usually occur at the germination stage. The impact on salinity to the seed germination is attributed to various changes in mobilization of stored reserves and affecting structural organization of protein [1]. Response to salt by the crops of may be quite different during seed germination under the accumulation of soluble salts around the seeds which increased the osmotic pressure. This caused excessive uptake of salts and which resulted in toxicity to the plant. Moreover water potential gradient (reduced water availability) between the external environment and the seeds also inhibited the primary root emergence. The current study was designed to investigate the effect of salt stress on seed germination, root and shoot length of rice, black gram and cotton.

\section{Materials and Methods}

A laboratory study was conducted at the Department of Agronomy, Faculty of Agriculture, Annamalai University to study the effects of salt stress on seed germination, root and shoot length of rice, black gram, cotton and the seeds were collected from the Experimental farm, Department of Agronomy. The collected seeds were put in Petri plates contained double filter paper soaked with $100 \mathrm{ml}$ distilled water, $0.05 \mathrm{~m}, 0.10 \mathrm{~m}$ and $0.25 \mathrm{~m} \mathrm{NaCl}$ solution. During that period seeds were kept at dark condition under room temperature $\left(28^{\circ} \mathrm{C}\right)$ for 4 days so that to provide favourable condition for germination. The readings were taken every $12 \mathrm{hrs}$ for 4 days allowed to grow further 3 days root, shoot length was measured and recorded. 


\section{Open Access Journal of Agricultural Research}

\section{Result}

The results of the laboratory study revealed that there was a slight numerical differences in germination in treated/untreated seeds at the initial stage. Increase in the concentration of Nacl solution led to reduce the germination percentage and generally caused a progressive retardation in germination. At the higher salinity levels, germination percentage was almost ceased. In paddy seeds maximum germination percentage for untreated seeds was 100 percent while it decreased to 30 percent at 0.25 molar salinity stress. In control, seeds started to germinate within thirty six hours, while the seeds in rest of salt treatment started after fourty eight hours. Seeds are not germinated even after 7 days of sowing at a concentration of $0.50 \& 0.75$ molar salinity stress. The same trend was observed in crops like blackgram and cotton which are sensitive to salt stress. The root and shoot lengths were measured after 10 days germination. In rice, cotton and blackgram the seedlings showed declined result in root and shoot lengths. The continues declined in root length was observed from control t 0.25 molar salinity. Shoot length was also similar to that of root length. There was significant reduction in length of shoots at 0.25 molar salinity in all crops. The inhibition of seed germination occurred with increased salt concentration which could be due to ion toxicity/ osmosis. It has been investigated that the germination of seeds, survival of seedlings and overall plant growth is reduced due to high salt concentration in the selected three crops.

\begin{tabular}{|c|c|c|c|c|c|c|c|}
\hline \multirow{2}{*}{$\begin{array}{c}\text { Concentration } \\
\text { (molar) }\end{array}$} & \multirow{2}{*}{$\begin{array}{c}\text { No. of seeds used in } \\
\text { petri plates }\end{array}$} & \multicolumn{3}{|c|}{ No. of seeds germinated } & \multicolumn{3}{c|}{ Germination percentage (\%) } \\
\cline { 2 - 8 } & & Rice & Blackgram & Cotton & Rice & Blackgram & Cotton \\
\hline Control & 10 & 10 & 10 & 10 & 100 & 100 & 100 \\
\hline 0.05 & 10 & 9 & 7 & 6 & 90 & 90 & 90 \\
\hline 0.1 & 10 & 8 & 6 & 5 & 80 & 80 & 80 \\
\hline 0.25 & 10 & 3 & 3 & 1 & 30 & 30 & 10 \\
\hline 0.5 & 10 & - & - & - & - & - & - \\
\hline 0.75 & 10 & - & - & - & - & - & - \\
\hline
\end{tabular}

Table 1: Germination percentage.

\begin{tabular}{|c|c|c|c|c|c|c|}
\hline \multirow{2}{*}{ Concentration (molar) } & \multicolumn{3}{|c|}{ Root length (cm) } & \multicolumn{3}{c|}{ Shoot length (cm) } \\
\cline { 2 - 7 } & Rice & Blackgram & Cotton & Rice & Blackgram & Cotton \\
\hline Control & 5.4 & 7.3 & 9.3 & 5.6 & 7.7 & 9.8 \\
\hline 0.05 & 6.18 & 6.4 & 8.6 & 3.7 & 6.1 & 8.4 \\
\hline 0.1 & 4.16 & 4.2 & 4.2 & 2.5 & 5.3 & 4.3 \\
\hline 0.25 & 0.33 & 1.1 & 1 & 0.2 & 0.8 & 0.4 \\
\hline 0.5 & - & - & - & - & - & - \\
\hline 0.75 & - & - & - & - & - & - \\
\hline
\end{tabular}

Table 2: Root and shoot length $(\mathrm{cm})$.

\section{References}

1. Manchando HR, Bhandri DK (1976) Effect of presoaking of seeds in salt solutions on the yield of wheat and barley irrigated with highly saline water. J Indian Soc Soil Sci 24: 432-435. 